\title{
Fine Structural Changes in the Endolymphatic Sac Induced by Calcium Loading in the Tree Frog, Hyla arborea japonica*
}

\author{
Seiichi KAWAMATA \\ Department of Anatomy, Toyama Medical and Pharmaceutical University, Toyama, Japan
}

Received February 13, 1990

Summary. The growth rate of calcium carbonate $\left(\mathrm{CaCO}_{3}\right)$ crystals in the endolymphatic sac was modulated, and morphological changes in this organ were observed by light and electron microscopy. When calcium chloride $\left(\mathrm{CaCl}_{2}\right)$ was given to the tree frog for a short period (3 days to 2 weeks), $\mathrm{CaCO}_{3}$ crystal production was accelerated. Epithelial cells enlarged, their rough endoplasmic reticulum (rER) and Golgi apparatus developed, and dense material increased around $\mathrm{CaCO}_{3}$ crystals and/or in the endolymphatic lumen. In addition, multiluminal endolymphatic chambers appeared in some frogs. On the other hand, as the $\mathrm{CaCl}_{2}$ loading period lengthened and $\mathrm{CaCO}_{3}$ crystal formation decreased or stopped, the epithelial cells became flat and extended with scanty cytoplasm, and the rER and Golgi apparatus decreased in number and size. Furthermore, the amount of dense material around $\mathrm{CaCO}_{3}$ crystals and in the lumen decreased. These findings suggest that the rER, Golgi apparatus and dense material have key roles in the production of $\mathrm{CaCO}_{3}$ crystals.

The formation process of $\mathrm{CaCO}_{3}$ crystals in the inner ear has been intensively studied by observing the shape, size and other features of $\mathrm{CaCO}_{3}$ crystals (BÉLANGER, 1960; VEENHOF, 1969; Ross and PEACOR, 1975; NAKAHARA and BEVELANDER, 1979; BALLARINO and Howland, 1982). Not enough attention has been directed, however, to the intracellular events in $\mathrm{CaCO}_{3}$ production. This is due in part to the fact that crystal growth in the inner ear of adult mammals is very slow or arrested (BÉLANGER, 1960; VEENHOF, 1969; PRESTON et al., 1975; Ross, 1979). Some investigators have observed $\mathrm{CaCO}_{3}$ production by epithelial cells of the developing inner ear (CigES et al., 1983); however, this process is not fully understood.
The tree frog is a good model for a study of this process because $\mathrm{CaCO}_{3}$ crystals grow in the endolymphatic sac, and their growth rate can be manipulated by loading the frogs with $\mathrm{CaCl}_{2}$. When the $\mathrm{CaCl}_{2}$ loading period is short, crystal production is accelerated (SCHLUMBERGER and BURK, 1953; KAWAMATA, $1987 \mathrm{a}, \mathrm{b})$, but when the loading period is lengthened, crystal growth stops partly or completely (KAWAMATA, 1988). Such a functional change in $\mathrm{CaCO}_{3}$ formation would probably be accompanied by fine structural changes in the endolymphatic sac. However, no such information has been reported. In this study, tree frogs were loaded with $\mathrm{CaCl}_{2}$ for up to 7 weeks, and morphological changes in endolymphatic epithelial cells, their organelles, and the luminal contents of the endolymphatic chambers were observed. This was done to elucidate the formation process of $\mathrm{CaCO}_{3}$ crystals and to solve related problems such as the response of the epithelium to increases in luminal contents.

\section{MATERIALS AND METHODS}

Nineteen tree frogs, captured in Toyama City and weighing between 1 and $2 \mathrm{~g}$, were used for this study. Three frogs were fixed immediately after capture. The other frogs were kept in a small aquarium with a shallow pool of $0.8 \% \mathrm{CaCl}_{2}$ solution for 3 days, or for $1,2,4,6$ or 7 weeks, varying by group. Each group consisted of 3 frogs, with only 1 being loaded with $0.8 \% \mathrm{CaCl}_{2}$ for 7 weeks. The frogs usually stayed at the side and top walls of the aquarium. They were easily accessible to $0.8 \% \mathrm{CaCl}_{2}$ ad libitum. The $0.8 \%$

\footnotetext{
*This study was supported by a grant from the Japan Ministry of Education, Science and Culture (No. 02807002).
} 
$\mathrm{CaCl}_{2}$ was changed every one or two days. Feeding was halted. The animals were then decapitated and processed as described in a previous paper (KAWAMATA et al., 1987). In short, segments of their spinal columns were immediately immersed for $4 \mathrm{~h}$ in a fixative containing $1 \%$ paraformaldehyde, $1.25 \%$ glutaraldehyde, $0.05 \mathrm{M}$ cacodylate buffer ( $\mathrm{pH} 7.4$ ) and $\mathrm{CaCl}_{2}(250 \mathrm{mg} /$ liter $)$ and then postfixed for $4 \mathrm{~h}$ in $1 \%$ $\mathrm{OsO}_{4}$ buffered with $0.05 \mathrm{M}$ cacodylate buffer ( $\mathrm{pH}$ 7.4). This was followed by three changes of $0.15 \mathrm{M} \mathrm{NaCl}$. Specimens were then transferred to $2 \%$ ascorbic acid in $0.15 \mathrm{M} \mathrm{NaCl}$ for 1 week to induce decalcification (DiETRICH and FonTAINe, 1975). After decalcification they were rinsed again three times with $0.15 \mathrm{M} \mathrm{NaCl}$ and stained en bloc in 3\% uranyl acetate for $1 \mathrm{~h}$. They were dehydrated, soaked in propylene oxide, and embedded in epoxy resin. Semithin sections (about $1 \mu \mathrm{m}$ ) were stained with $0.5 \%$ toluidine blue in $0.5 \%$ sodium borate and observed under a light microscope. Ultrathin sections were stained with uranyl acetate and lead citrate, and then observed with a JEM-100S transmission electron microscope.

\section{RESULTS}

\section{Endolymphatic chambers of the tree frog immediately after capture}

The endolymphatic sac is composed of numerous chambers lined by a simple squamous or cuboidal epithelium. The fine structure of the endolymphatic chambers of the frogs in this group was generally the same as that of frogs starved for one month (KAWAMATA et al., 1987), although wider variation from one chamber to another was found. The height of the epithelial cells within a given chamber was also found to vary from one part to another. Cytoplasmic granules seemed fewer (Fig. 1) than previously reported (KAWAMATA et al., 1987). The few $\mathrm{CaCO}_{3}$ crystals were covered by a thin or fragmentary dense material.

\section{Endolymphatic chambers loaded with $\mathrm{CaCl}_{2}$ for 3 days}

As a whole, the endolymphatic chambers were similar at the light microscopic level to those of the frogs fixed immediately after capture. However, careful observation revealed that the $\mathrm{CaCO}_{3}$ crystals were sometimes demarcated by a thicker dense material (Fig. 2a). The lumina of a few chambers contained a considerable amount of free dense material (Figs. 2b, 3 ). The dense material around crystals was stained reddish purple with toluidine blue and showed metachromasia. The free dense material was almost blue; metachromasia was not distinct. Floating cells with vacuoles and small multiluminal chambers were infrequently observed (Fig. 2c). The electron microscope revealed vacuolar rER with speckled contents within the epithelial cells (Fig. 4). The number of cytoplasmic granules was small and varied from one cell to the next.

\section{Endolymphatic chambers loaded with $\mathrm{CaCl}_{2}$ for 1 and 2 weeks}

In these groups, the number of $\mathrm{CaCO}_{3}$ crystals in the lumen was apparently greater than that seen without $\mathrm{CaCl}_{2}$ loading. Epithelial cells were often large and contained plenty of cytoplasm. Although vacuolar rER was scant, stacks of flat rER were found in some epithelial cells. The Golgi apparatus was relatively well-developed (Fig. 5a, b). Somewhat greater numbers of cytoplasmic granules were present, some of them having speckled contents similar to those of vacuolar $\mathrm{rER}$. A close relationship between the Golgi apparatus and cytoplasmic granules was also observed.

In 1 of the 3 frogs in each group, most endolymphatic chambers were composed of more than one lumen (multiluminal chambers) (Figs. 5c, 6). Lumina varied in shape and size, with small lumina frequently observed in the epithelial layer. The epithelium separating the adjacent lumina of a chamber consisted of

Fig. 1. Endolymphatic epithelial cell of a tree frog immediately after capture. Arrowheads cytoplasmic granules. $\times 6,800$

Figs. 2-4. Endolymphatic chambers of tree frogs loaded with $\mathrm{CaCl}_{2}$ for 3 days. Fig. 2a. Crystals are demarcated by a thick dense material (arrowheads). Light micrograph. $\times 1,000$. Fig. 2b. The lumen is filled with much dense material and crystals. Light micrograph. $\times 800$. Fig. 2c. Small multiluminal chamber. Small lumina (asterisks) are observed in the epithelial layer. A floating cell (arrow) with large vacuoles appears in the lumen. Light micrograph. $\times 1,100$. Fig. 3. Electron micrograph of the chamber shown in Fig. 2b. Note the dense material among crystals. $\times 4,400$. Fig. 4 . Vacuolar rER (arrows) contains a speckled substance. $G$ Golgi apparatus. $\times 7,400$ 

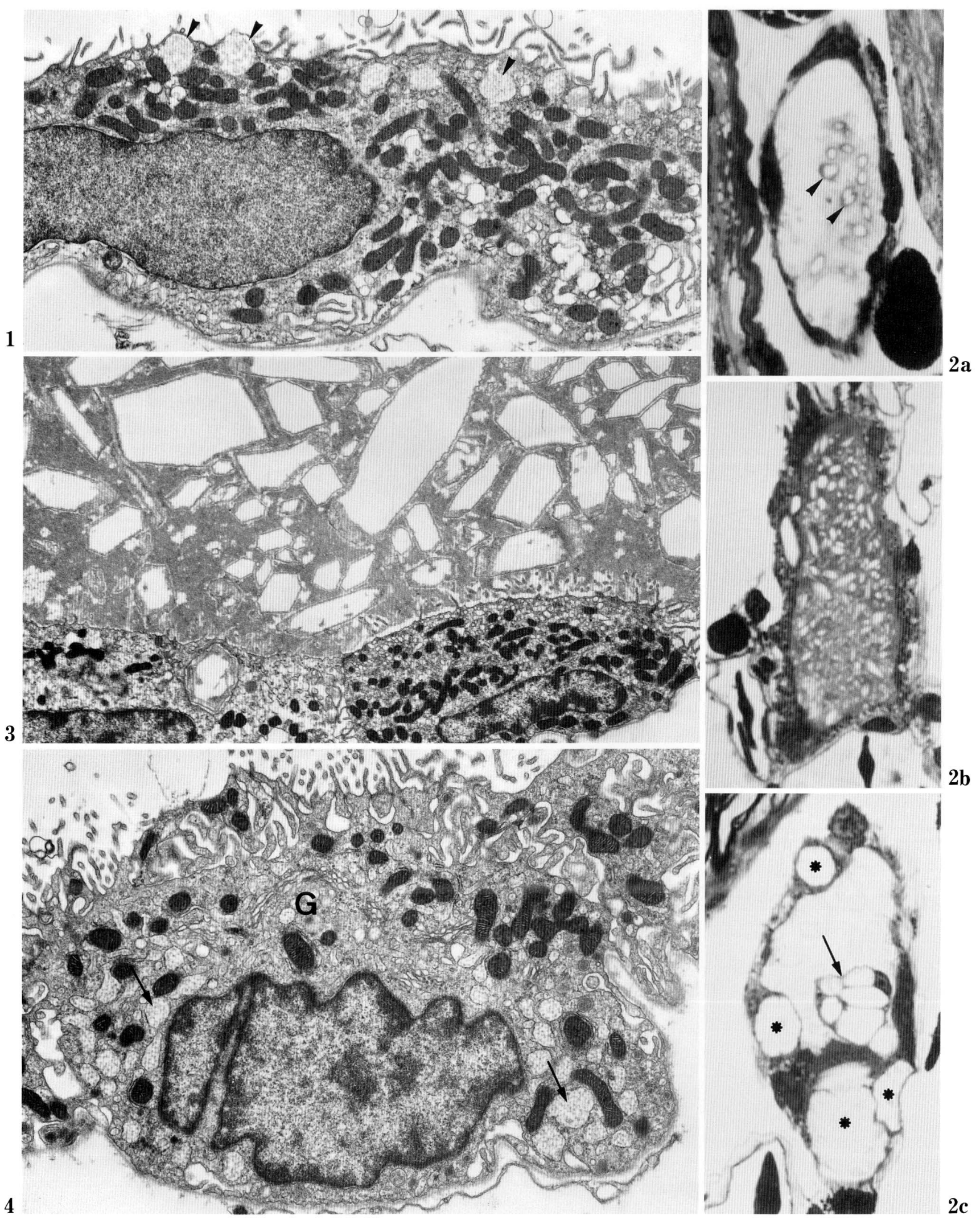

Figs. 1-4. Legends on the opposite page. 


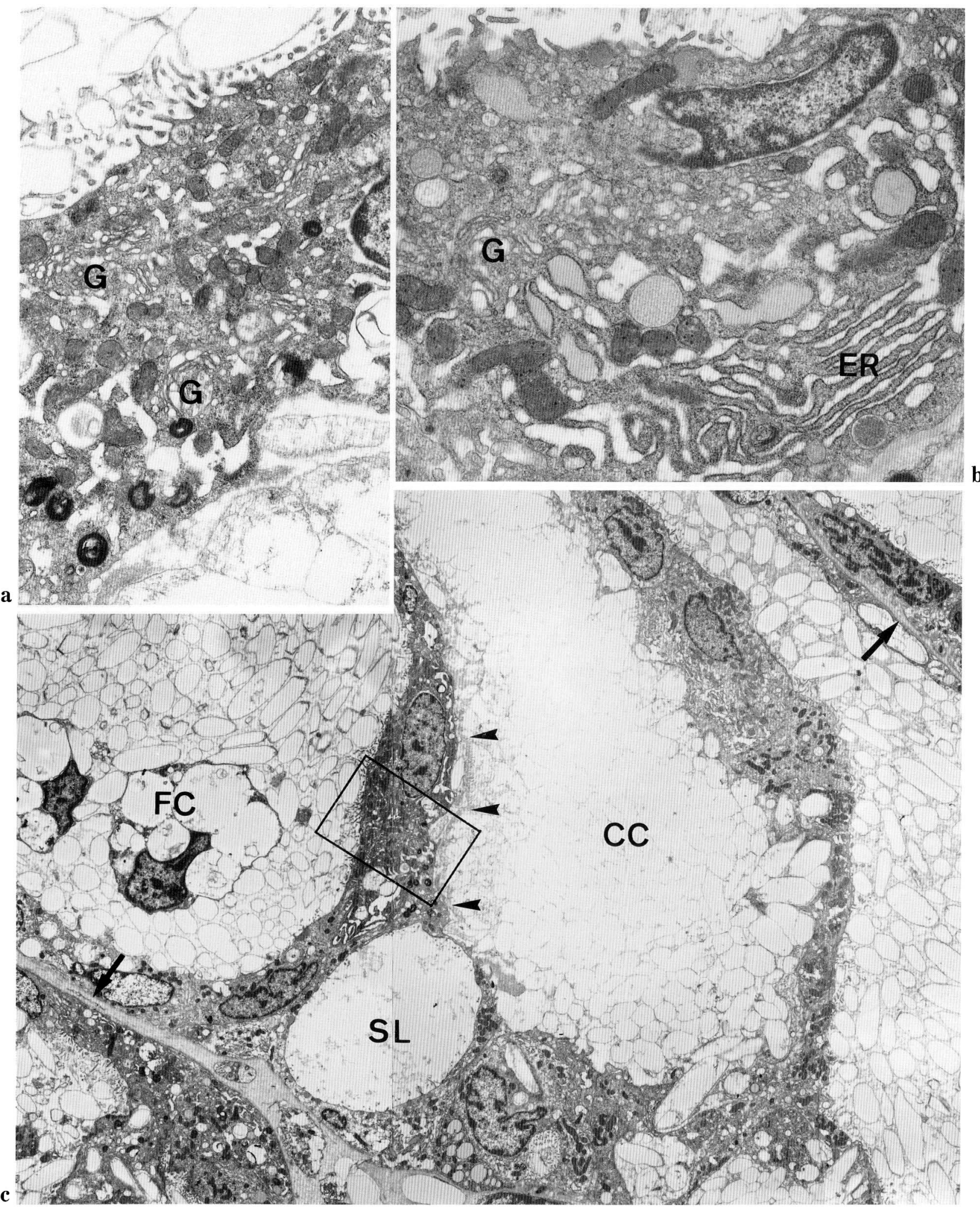

Fig. 5. Legend on the opposite page. 
a single epithelial layer without a basement membrane (Fig. 5a, c). Discontinuities in this separating epithelium were sometimes encountered. On the other hand, two adjacent endolymphatic chambers were separated by two epithelial layers, their basement membranes and some connective tissue, even if the epithelium was very thin (Fig. 5c). Mitotic figures were rarely seen among the epithelial cells. Endolymphatic lumina often contained crystals with thicker dense material and/or floating cells with large vacuoles (Fig. $5 \mathrm{c}$ ). The thickness of the dense material around the crystals was usually uniform within a single lumen, but varied from one lumen to another (Figs. 6, 7a). On occasion, the dense material was found even in the center of the crystals (Fig. 7b). The dense material of conglomerate crystals sometimes formed a common peripheral metachromatic layer (Figs. 5c, 6). This was more frequently observed in frogs loaded with $\mathrm{CaCl}_{2}$ for 2 weeks.

Most endolymphatic chambers seemed activated as mentioned above, however, a few endolymphatic chambers in frogs loaded with $\mathrm{CaCl}_{2}$ for 2 weeks had flat epithelial cells and the thin dense material around their crystals. This finding resembled the observations of frogs loaded with $\mathrm{CaCl}_{2}$ for 4 weeks or longer period.

\section{Endolymphatic chambers loaded with $\mathrm{CaCl}_{2}$ for 4,6 and 7 weeks}

The endolymphatic chambers appeared to have increased in size but not in number. In general, the longer the animals were loaded with $\mathrm{CaCl}_{2}$, the more expanded the chambers became. In these frogs no multiluminal chambers were found. Neither the thick dense material around the crystals nor floating cells were recognized in the lumen. Epithelial cells were very flat and extended (Fig. 8), and their luminal surfaces were often indented by crystals pressing against them. In the peripheral zone of the lumen, cellular debris such as mitochondria was occasionally observed among the crystals. The epithelial cells had elongated or oval nuclei and scanty cytoplasm (Fig. 9). Because of the scarcity of cytoplasm, cell organelles such as rER, Golgi apparatus and cytoplasmic granules were few.

\section{Other findings}

Exocytosis of cytoplasmic granules was difficult to recognize. Electron dense spherules or deposits (KAWAmATA et al., 1987) were found beneath the basement membrane of the epithelium in several groups. Such deposits were not observed within the cells.

\section{DISCUSSION}

This study verified that the fine structure of the endolymphatic sac changes in relation to the functional activity of this organ. Without calcium loading, little rER was observed in the endolymphatic epithelial cells (KAWAMATA et al., 1987; present study), and $\mathrm{CaCO}_{3}$ crystals hardly grew (KAWAMATA, 1987b). After short-term calcium loading, epithelial cells, their rER and Golgi apparatus were usually activated. This observation suggests that the rER and Golgi apparatus are deeply involved in the process of crystal formation. Cytoplasmic granules are probably produced through the rER and Golgi apparatus. In addition to these changes, an increase in dense material was also noted. In a forthcoming report (KAWAMATA, 1990), it has been noted that granules have little calcium which reacts with pyroantimonate. Thus, the granules may contain a dense material or its precursor and are perhaps released into the lumen. Some crystals had dense material even in their centers. A similar distribution of dense material has usually been observed in mammalian otoconia (LIM, 1973; NAKAHARA and Bevelander, 1979; IмоTo et al., 1983), and the appearance of vacuole-containing cells has been reported in the $\mathrm{CaCO}_{3}$-producing endolymphatic lumen of the guinea pig (Iмото et al., 1983).

The dense material of mammalian otoconia, studied extensively, has been termed the organic matrix (VEENhoF, 1969; BALSAMO et al., 1969; ERWAY et al., 1970; LIM, 1973; FERMIN and IGARASHI, 1985), organic fraction (BÉLANGER, 1960) or organic material (Ross and PEACOR, 1975; SAlamat et al., 1980). BÉlanger (1960) stated that the organic fraction contains acid and neutral mucopolysaccharides. BALSAMO et al.

Fig. 5. Endolymphatic chamber loaded with $\mathrm{CaCl}_{2}$ for 1 week. a. High magnification of the area marked in Fig. 5 c. Note the absence of a basement membrane. $G$ Golgi apparatus. $\times 8,200$. b. Stacks of rER $(E R)$ and relatively well-developed Golgi apparatus $(G)$ are seen. $\times 12,000$. c. Multiluminal chamber with several lumina separated by single epithelial cell layers. Adjacent chambers are divided by two layers of basement membranes and a connective tissue (arrows). Conglomerate crystals (CC) form a partial common dense layer (arrowheads). FC floating cells with large vacuoles, $S L$ small lumen. $\times 1,700$ 

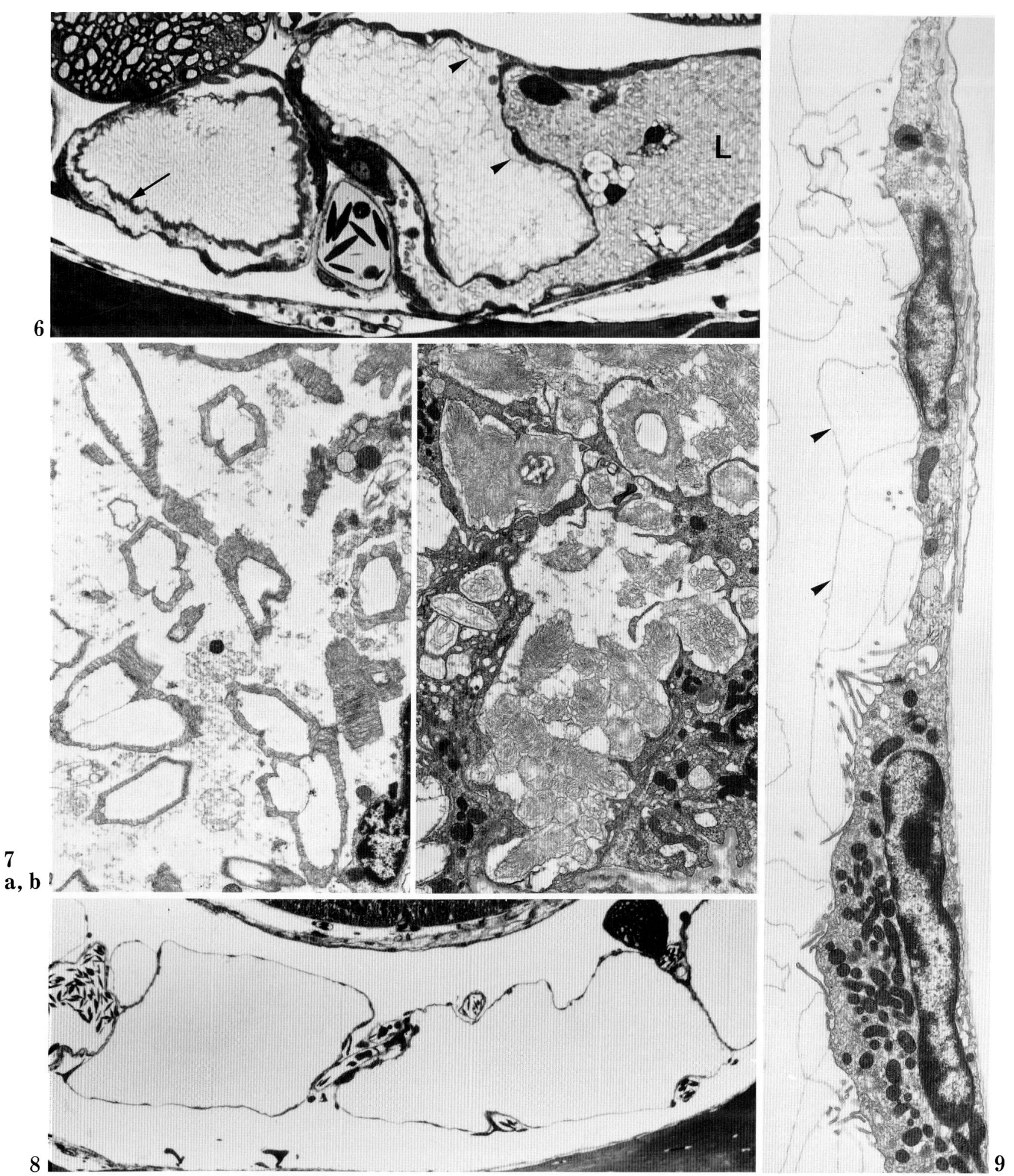

Figs. 6-9. Legends on the opposite page. 
(1969) thought that the organic matrix consisted of mucopolysaccharides and proteins. VEENHOF (1969) described the organic matrix as being made of neutral sugars, which appear solely in the crystallization period, and acid protein-polysaccharides. ERWAY et al. (1970) reported that the organic matrix stained metachromatically, and thus concluded that it consists of acid mucopolysaccharides. In the present study, the dense material around the crystals also exhibited metachromasia. Therefore, the dense material around the crystals in tree frogs is considered to be very similar to the organic matrix of the mammalian otoconia.

The so-called organic matrix of mammals is considered very important for $\mathrm{CaCO}_{3}$ crystal formation. In fact, ERWAY et al. (1970) observed no organic matrix in manganese-deficient mice that lacked otoconia. It was demonstrated that the dense material binds calcium and plays an important role in crystal growth (see next report; KAWAMATA, 1990). The thickness of the dense material around the crystals was usually uniform in the same lumen, but varied from one lumen to the next in the present study, especially when the frogs were loaded with $\mathrm{CaCl}_{2}$ for 1 or 2 weeks. This means that the microenvironment of crystals is regulated at the luminal level, and probably explains the functional heterogeneity among lumina (KAWAMATA, 1988). A common metachromatic dense layer around conglomerate crystals may indicate the fusion of crystals (Figs. 5c, 6).

After long-term calcium loading, the epithelial cells became flat and extended. Mitotic figures among epithelial cells were rare in all groups. These observations indicate that flattening and extension of the epithelial cells are the main reactions of the endolymphatic sac to the expansion of the luminal contents. It has been reported that the growth of endolymphatic crystals stops partly or completely after long-term calcium loading (KAWAMATA, 1988). The mechanism of decreased crystal growth may be attributed mainly to the decrease in rER, Golgi apparatus and dense material, and partly to secondary effects of stretching or other influences on epithelial cells.

Numerous multiluminal chambers were observed in 1 of the 3 frogs loaded with $\mathrm{CaCl}_{2}$ for 1 and 2 weeks, respectively. The lumina of the multiluminal chambers varied in number and size. Small lumina, which were commonly observed in the epithelial layer, probably increased in size. An interesting finding is that the epithelial layer separating the lumina faces two or more lumina which have no basement membrane. Discontinuity in this separating epithelium indicates that many, if not all, lumina will finally rupture and fuse. Taking the fine structures of the endolymphatic sac and dense material into account, it seems reasonable to assert that the endolymphatic sac is most active in frogs loaded for a duration of 1 to 2 weeks. However, the endolymphatic chambers with flat epithelial cells and the thin dense material around crystals were rarely encountered as early as 2 weeks after the start of Ca-loading. This finding means that endolymphatic chambers of various functional activities coexist in the same frog. The inactivated endolymphatic chambers probably increase their number in frogs loaded with $\mathrm{CaCl}_{2}$ for more than 2 weeks under these experimental conditions.

Acknowledgements. The author is grateful to Mr. M. KAWAHARA for his technical assistance and wishes to thank Prof. K. TAKAYA for his critical reading of the manuscript.

Fig. 6. Single (left) and multiluminal (right) chambers loaded with $\mathrm{CaCl}_{2}$ for 2 weeks. The common dense layer is thick (arrow) or thin (arrowheads). Note the uniformly thick dense material around each crystal in the right lumen $(L)$. Light micrograph. $\times 700$

Fig. 7. Electron micrographs of the dense material. a. The thick dense material around crystals loaded with $\mathrm{CaCl}_{2}$ for 2 weeks. $\times 4,400$. b. Crystals loaded with $\mathrm{CaCl}_{2}$ for 1 week. Dense material is seen even in the center of the crystals. $\times 4,100$

Fig. 8. Endolymphatic chambers loaded with $\mathrm{CaCl}_{2}$ for 7 weeks. Epithelial cells are very flat and extended. Dense material is not seen. Light micrograph. $\times 170$

Fig. 9. Flat and extended epithelial cells loaded with $\mathrm{CaCl}_{2}$ for 6 weeks. Notice the thin dense material (arrowheads). $\times 6,000$ 


\section{REFERENCES}

Ballarino, J. and H. C. Howland: Otoconial morphology of the developing chick. Anat. Rec. 204: 83-87 (1982).

Balsamo, G., M. De Vincentis and F. Marmo: The effect of tetracyclin on the processes of calcification of the otoliths in the developing chick embryo. J. Embryol. Exp. Morphol. 22: 327-332 (1969).

Bélanger, L. F.: Development, structure and composition of the otolithic organs of the rat. In: (ed. by) R. F. SognnAES: Calcification in biological systems. American Association for the Advancement of Science, Washington, 1960 (p. 151-162).

Ciges, M., A. Campos and F. Revelles: The origin of the otoconia in the rat. Acta Otolaryngol. (Stockh.) 95: 522-527 (1983).

Dietrich, H. F. and A. R. Fontaine: A decalcification method for ultrastructure of echinoderm tissues. Stain Technol. 50: 351-354 (1975).

Erway, L., L. S. Hurley and A. S. Fraser: Congenital ataxia and otolith defects due to manganese deficiency in mice. J. Nutr. 100: 643-654 (1970).

Fermin, C. D. and M. Igarashi: Development of otoconia in the embryonic chick (Gallus domesticus). Acta Anat. 123: 148-152 (1985).

IMoTo, T., H. RASK-ANDERSEN and D. BAGGER-SJöBÄCK : The role of the endolymphatic sac in statoconial formation and degradation. Acta Otolaryngol. (Stockh.) 96: 227-235 (1983).

KAW MATA, S.: Incorporation of strontium into the calcium carbonate crystals of the endolymphatic sac in the tree frog (Hyla arborea japonica). Anat. Rec. 218: 223228 (1987a).

- Growth aspects of calcium carbonate crystals of the endolymphatic sac in the tree frog (Hyla arborea japonica). A pulse-chase study. J. Electron Microsc. 36 : 392-397 (1987b).

- :ffects of calcium preloading on the growth of calcium carbonate crystals in the endolymphatic sac of the tree frog, Hyla arborea japonica. Cell Tiss. Res. 252: 679-682 (1988).

-: Localization of pyroantimonate-precipitable calcium in the endolymphatic sac of the tree frog, Hyla arborea japonica. Arch. Histol. Cytol. 53: 405-411 (1990).
Kawamata, S., K. Takaya and T. Yoshida: Light- and electron-microscopic study of the endolymphatic sac of the tree frog, Hyla arborea japonica. Cell Tiss. Res. 249: 57-62 (1987).

LIM, D. J.: Formation and fate of the otoconia. Scanning and transmission electron microscopy. Ann. Otol. Rhinol. Laryngol. 82: 23-35 (1973).

Nakahara, H. and G. Bevelander: An electron microscope study of crystal calcium carbonate formation in the mouse otolith. Anat. Rec. 193: 233-242 (1979).

Preston, R. E., L.-G. Johnsson, J. H. Hill and J. ScHACHT: Incorporation of radioactive calcium into otolithic membranes and middle ear ossicles of the gerbil. Acta Otolaryngol. (Stockh.) 80: 269-275 (1975).

Ross, M. D.: Calcium ion uptake and exchange in otoconia. Adv. Otorhinolaryngol. 25: 26-33 (1979).

Ross, M. D. and D. R. Peacor: The nature and crystal growth of otoconia in the rat. Ann. Otol. Rhinol. Laryngol. 84: 22-36 (1975).

Salamat, M. S., M. D. Ross and D. R. Peacor: Otoconial formation in the fetal rat. Ann. Otol. Rhinol. Laryngol. 84: 229-238 (1980).

Schlumberger, H. G. and D. H. Burk: Comparative study of the reaction to injury. II. Hypervitaminosis D in the frog with special reference to the lime sacs. A. M. A. Arch. Pathol. 56: 103-124 (1953).

VeEnhoF, V. B.: The development of statoconia in mice. Verhandelingen der Koninklijke Nederlandse Akademie van Wetenschappen, Afd. Natuurkunde 2/58, No. 4. N. V. North-Holland Publ. Co., AmsterdamLondon, 1969.

\author{
Dr. Seiichi Kawamata \\ Department of Anatomy \\ Toyama Medical and Pharmaceutical University \\ 2630 Sugitani, Toyama \\ 930-01 Japan \\ 川真田 聖 一 \\ 930-01 富山市杉谷 2630 \\ 富山医科薬科大学医学部 \\ 第二解剖学教室
}

